\title{
Macular edema associated with gyrate atrophy managed with intravitreal triamcinolone: a case report
}

\author{
Edema macular associado a atrofia girata tratado com triancinolona intravítrea: \\ relato de caso
}

\author{
Daniel Vítor Vasconcelos-Santos ${ }^{1}$ \\ Érika Pacheco Magalhães ${ }^{2}$ \\ Márcio Bittar Nehemy ${ }^{3}$
}

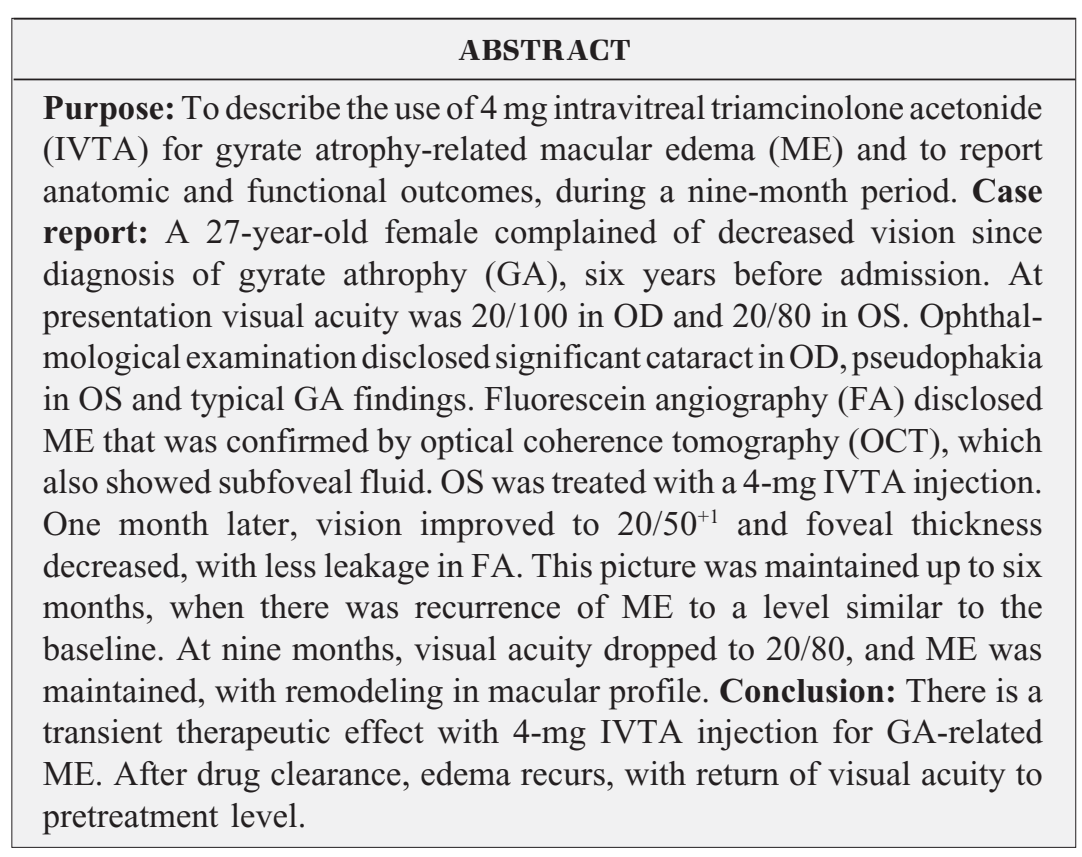

Keywords: Gyrate atrophy/drug therapy; Macular edema, cystoid/drug therapy; Triamcinolone acetonide/therapeutic use; Relatos de casos [Tipo de publicação]

Trabalho realizado no Serviço de Retina e Vítreo do Hospital São Geraldo - Universidade Federal de Minas Gerais - UFMG - Belo Horizonte (MG) - Brasil e no Instituto da Visão - Belo Horizonte (MG) - Brasil.

Doutor em Oftalmologia pela Universidade Federal de Minas Gerais - UFMG - Belo Horizonte (MG) - Brasil. Doutora em Oftalmologia pela UFMG - Belo Horizonte (MG) - Brasil.

Professor Adjunto, Chefe dos Serviços de Retina e Vítreo da Faculdade de Medicina da UFMG - Belo Horizonte (MG) - Brasil e do Instituto da Visão - Belo Horizonte (MG) - Brasil.

Endereço para correspondência: Daniel V. Vasconcelos-Santos. Rua João de Freitas, 73/401 - Belo Horizonte (MG) CEP 30350-100

E-mail: dvitor@ufmg.br

Recebido para publicação em 30.11.2006

Última versão recebida em 27.02.2007

Aprovação em 26.03.2007

Nota Editorial: Depois de concluída a análise do artigo sob sigilo editorial e com a anuência da Dra. Maria Teresa Brizzi Chizzotti Bonanomi sobre a divulgação de seu nome como revisora, agradecemos sua participação neste processo.

\begin{abstract}
$\frac{\text { INTRODUCTION }}{\text { Decreased vision in patients with gyrate atrophy (GA) may be due to }}$ retinal atrophy, cataract development or macular edema ${ }^{(1)}$. Treatment options for GA remain limited. Intravitreal triamcinolone acetonide (IVTA) has gained projection as a promising therapeutic modality for a wide range of retinal disease ${ }^{(2)}$, but its use in GA-related macular edema has not been reported yet. This paper aims to prospectively describe the use of $4 \mathrm{mg}$ intravitreal triamcinolone acetonide for gyrate atrophy-related macular edema and to report the anatomic and functional results, during a nine month period.
\end{abstract}

\section{CASE REPORT}

A 27-year-old female had a diagnosis of gyrate atrophy for six years and sought the university hospital complaining of decreased vision in both eyes. She had been previously treated with topical ketorolac tromethamine associated with topical prednisolone and oral acetazolamide for six weeks, 
with no improvement. At presentation, best-corrected visual acuity (BCVA) was 20/100 in OD and 20/80 in OS. Anterior segment examination disclosed significant anterior and posterior subcapsular cataract in OD and an in-the-bag intraocular lens, with a Nd:YAG laser posterior capsulotomy in OS. Fundus examination showed typical GA findings (Figure 1A). Fluorescein angiography (FA) disclosed slight late foveal leakage (Figure 1B) and optical coherence tomography (OCT) revealed marked macular edema and foveal serous detachment in both eyes (Figures 1C, D and 2A). The patient consented to go through IVTA (Kenalog-40; Bristol Myers Squibb Princeton, New Jersey, USA) injection in OS. One month later, BCVA improved to $20 / 50^{+1}$, FA showed decrease in leakage and OCT revealed some reduction of edema, with total macular volume (TMV) decreasing from $8.94 \mathrm{~mm}^{3}$ to $7.09 \mathrm{~mm}^{3}$ and central macular thickness (CMT) from $382 \pm 6 \mu \mathrm{m}$ to 362 $\pm 3 \mu \mathrm{m}$ (Figure 2B). After three months, BCVA was maintained $\left(20 / 50^{+3}\right)$ and FA images were similar to those at one month postinjection. Nevertheless, foveal edema partially recurred as revealed by $\mathrm{OCT}\left(\mathrm{TMV}=7.55 \mathrm{~mm}^{3}\right.$ and $\mathrm{CMT}=427$ $\pm 0 \mu \mathrm{m}$ (Figure 2C). Examination six months after injection showed stable BCVA in OS $\left(20 / 50^{+3}\right)$, but an additional increase in macular edema to a level similar to that before IVTA injection $\left(\mathrm{CMT}=435 \pm 4 \mu \mathrm{m}\right.$ and $\left.\mathrm{TMV}=8.8 \mathrm{~mm}^{3}\right)$, as depicted in Figure 2D. Final examination at nine months showed a drop in BCVA to $20 / 80^{+1}$, and maintenance of macular edema, although with a slightly different macular profile than that of the baseline $\left(\mathrm{CMT}=406 \mu \mathrm{m}, \mathrm{TMV}=9.07 \mathrm{~mm}^{3}\right)$ - Figure $2 \mathrm{E}$. Intraocular pressure was normal all over the follow-up.

\section{DISCUSSION}

The mechanism of macular edema in this subset appears to be related to malfunction of outer blood-retinal barrier, with diffusion of fluid towards intraretinal and subretinal spaces. It is possible that this involves an underlying autoimmune process ${ }^{(3)}$.

IVTA use in retinal dystrophies has led to some controversy $^{(3-4)}$. The decision to perform IVTA injection in this patient was based on failure of previous clinical treatment. OS was selected for injection because of its better media transparency compared to OD, in which there was significant lens opacity. That would allow sharper images of the macula on FA and OCT and also a more accurate evaluation of BCVA. Moreover IVTA injection carries the risk of cataract worsening.

Reduction in CMT and, particularly, in TMV were observed one month after injection. Nevertheless, OCT images at three and six months showed an even thicker macula center than that of the baseline. TMV was maintained nonetheless. It is important to notice that a variation of up to $10 \mu \mathrm{m}$ in retinal thickness of normal subjects measured on OCT shall not be considered significant, due to limited resolution of the devi$\mathrm{ce}^{(5)}$. Probably the fluctuations in CMT and TMV herein described may be due to fluid redistribution and macular remodeling. Other possibilities could have been rebound effect or natural progression of the edema. This outcome was not as good as those reported in eyes with retinitis pigmentosa $a^{(3,5)}$ and other exudative diseases ${ }^{(2,6)}$, in which total resorption of edema, with recovery of foveal depression is usually achieved, at least for some time. In fact, most of these exudative diseases show incompetence of inner hematoretinal barrier, that can be stabilized with $\operatorname{IVTA}^{(2,6)}$. It is possible that the outer hematoretinal barrier affected in GA and retinitis pigmentosa, for instance, may be less susceptible to IVTAmediated stabilization. Eventual influence of previous cataract surgery and posterior capsulotomy on our results is unknown. The reason for the stable visual acuity despite anatomic worsening until the $6^{\text {th }}$ month visit also remains speculative, although at the last examination, nine months after injection, BCVA dropped to a level similar to that of the baseline. It is possible that variable photoreceptor dysfunction may interfere with the correlation between macular edema disclosed by OCT and BCVA in gyrate atrophy. In diabetic macular edema, correlation between foveal thickness and visual acuity following IVTA has also been reported as not strong ${ }^{(7)}$. Subjective component of visual acuity testing should also be considered, even though patient information was sharp and examination was performed by the same physician (DVVS) at all time points. Moreover, refraction in the treated eye was also stable $\left(-0.75-1.00 \times 135^{\circ}\right)$ until the last
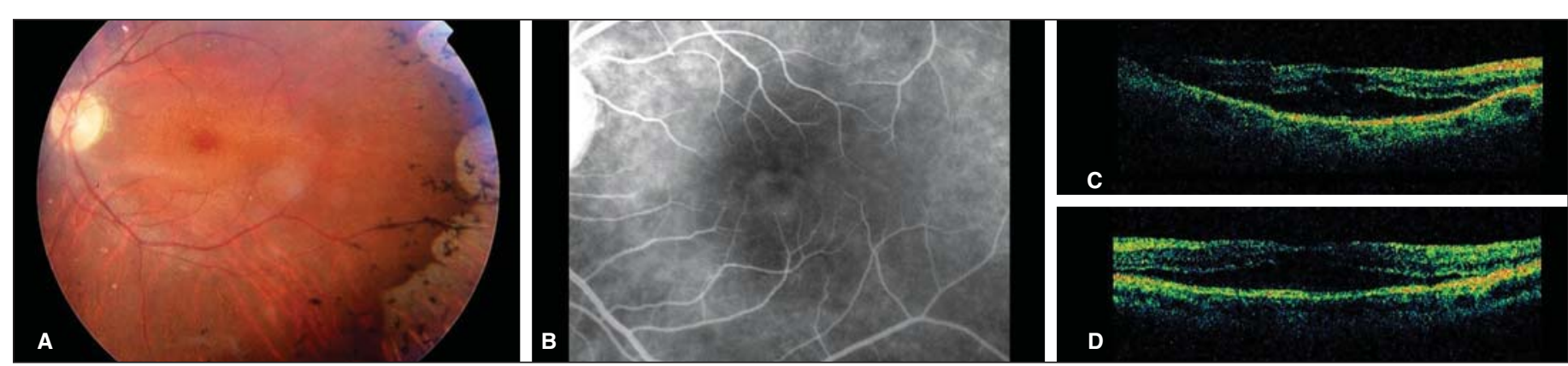

Figure 1 - Baseline features. A) OS fundus photograph, showing typical confluent patches of chorioretinal atrophy and pigment clumping, with an altered foveal reflex. B) OS late-phase fluorescein angiography, with faint perifoveal hyperfluorescence. C and D) OCT showing macular edema and foveal detachment in OD and OS, respectively. 

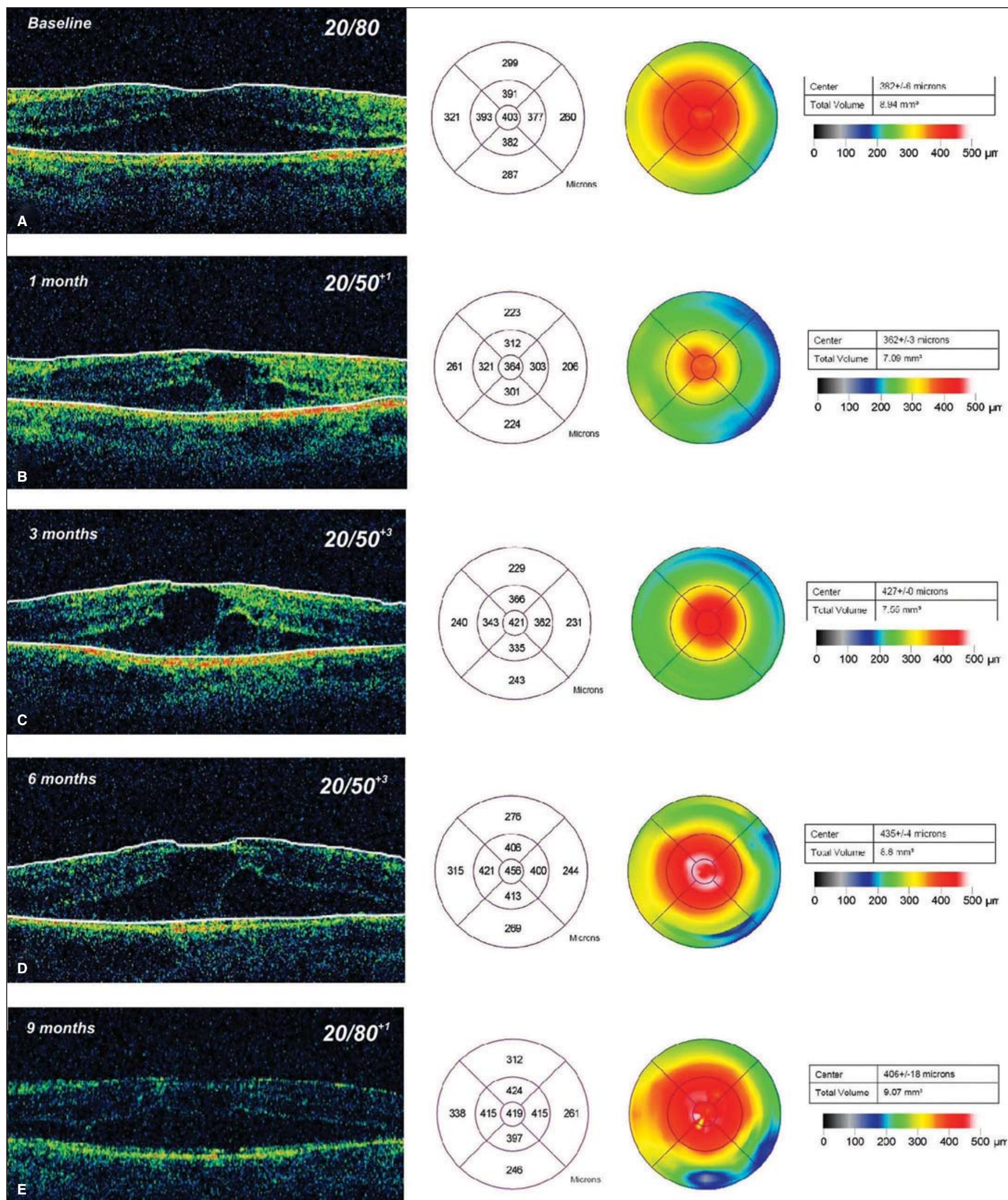

Figure 2 - OS OCT findings and corresponding best-corrected visual acuity at each time point. A) Baseline, with macular edema and subfoveal fluid. $B)$ One month after IVTA injection, showing more demarcation of cystic spaces and edema of less magnitude and extension. C) Three months after IVTA, with partial recrudescence of subretinal fluid. D) Six months after IVTA, with more fluid pooling under the fovea. E) Final examination at nine months, showing slight change in macular profile, but a similar amount of edema. 
follow-up visit. Further sequential physiologic testing such as visual field or contrast sensitivity examinations would have shed more light on this subject.

To our knowledge, this is the first case of GA-related macular edema treated with IVTA in the indexed literature. It shows a slight and transient therapeutic effect on resorption of intraretinal fluid, which might lead to a better central vision. Nevertheless, after drug clearance, edema may have a tendency to recur, with decrease in BCVA to pretreatment level. Further studies are needed to clarify this issue.

\section{RESUMO}

Objetivo: Descrever o uso de acetonida de triancinolona intravítrea (TAIV) em caso de edema macular (EM) associado a atrofia girata (AG). Relato do caso: Paciente de 27 anos, do sexo feminino, queixava-se de baixa de visão desde o diagnóstico de AG, há seis anos. À admissão, apresentava acuidade visual corrigida de 20/100 no OD e 20/80 no OE. Exame oftalmológico revelava catarata significativa no OD, pseudofacia no $\mathrm{OE}$ e achados típicos de AG. Angiografia fluoresceínica (AFG) mostrou EM, confirmado pela tomografia de coerência óptica (OCT), que também revelou líquido subfoveal. Foi então realizada injeção de $4 \mathrm{mg}$ de TAIV no OE. Após um mês, a visão melhorou para $20 / 50^{+1}$ e a espessura foveal se reduziu, com menos extravasamento à AFG. Esse quadro foi mantido até os seis meses, quando houve recorrência do edema macular em nível semelhante ao inicial. Aos nove meses, a visão retornou a 20/80 e o edema se manteve, com remodelamento no perfil macular. Conclusão: A injeção de $4 \mathrm{mg}$ de TAIV tem efeito transitório no EM associado a AG. Após a eliminação da droga, há recorrência do EM, com retorno da visão aos níveis pré-tratamento.

Descritores: Atrofia girata/quimioterapia; Edema macular cistóide/quimioterapia; Triancinolona acetonida/uso terapêutico; Case reports [Publication type]

\section{REFERENCES}

1. Potter MJ, Berson EL. Diagnosis and treatment of gyrate atrophy. Int Ophthalmol Clin. 1993;33(2):229-36.

2. Jonas JB, Kreissig I, Degenring R. Intravitreal triamcinolone acetonide for treatment of intraocular proliferative, exudative, and neovascular diseases. Prog Retin Eye Res. 2005;24(5):587-611.

3. Ozdemir H, Karacorlu M, Karacorlu S. Intravitreal triamcinolone acetonide for treatment of cystoid macular oedema in patients with retinitis pigmentosa. Acta Ophthalmol Scand. 2005;83(2):248-51.

4. Saraiva VS, Sallum JM, Farah ME. Treatment of cystoid macular edema related to retinitis pigmentosa with intravitreal triamcinolone acetonide. Ophthalmic Surg Lasers Imaging. 2003;34(5):398-400.

5. Hee MR, Puliafito CA, Duker JS, Reichel E, Coker JG, Wilkins JR, et al. Topography of diabetic macular edema with optical coherence tomography. Ophthalmology. 1998;105(2):360-70.

6. Maia Júnior OO, Takahashi WY, Bonanomi MTBC, Nascimento VP, Melo CSN. Injeção intravítrea de triancinolona no tratamento da telangiectasia retiniana justafoveolar idiopática. Arq Bras Oftalmol. 2006;69(6):941-4.

7. Larsson J, Zhu M, Sutter F, Gillies MC. Relation between reduction of foveal thickness and visual acuity in diabetic macular edema treated with intravitreal triamcinolone. Am J Ophthalmol. 2005;139(5):802-6. 